\title{
Geliat Puritanisme Islam di Indonesia: Menyibak Tabir di Balik Gerakan Majelis Tafsir Al-Qur'an (MTA) dalam Perspektif Sosiologis
}

\author{
Ilyya Muhsin, Muhammad Gufron \\ IAIN Salatiga \\ ilyya_mubsin@yaboo.com
}

\begin{abstract}
Purification movements conducted by MTA are very interesting to be studied. Although the form of a charismatic foundation with leadership, MTA puritan da'wah like a social organization, because it has an active organizational structure moving through various organs. Therefore, there is an interesting side to discussing this MTA in a sociological perspective, with the theory of social movements. The results can be seen from three aspects of social movements: first, taking advantage of political opportunities in the form of silatnas and early morning studies. Second, mobilizing resources, consisting of moral resources, namely the Qur'an-hadith and figures; cultural resources with various MTA business charities; human resources, with a structured cadre system; well-structured social-organizational resources, and tremendous financial resources. Third, arrange the movement process in solving various diseases of the people with the right solution for the MTA
\end{abstract}

Keywords: MTA, social movement, Purification.

\begin{abstract}
Abstrak
Gerakan purifikasi yang dilakukan MTA sangat menarik untuk dikaji. Meski berbentuk yayasan dengan kepemimpinan yang kharismatik, MTA berdakwah puritan seperti organisasi sosial, karena memiliki struktur organisasi yang aktif bergerak melalui berbagai organnya. Karena itu, ada sisi menarik membahas MTA ini dalam perspektif sosiologis, yakni dengan teori gerakan sosial. Hasilnya dapat dilihat dari tiga aspek gerakan sosial: pertama, memanfaatkan peluang politik dalam bentuk silatnas dan kajian ahad pagi. Kedua, memobilisasi sumber daya, yang terdiri dari sumber daya moral, yaitu Al-Qur'an-hadis dan figur; sumber daya kultural dengan berbagai amal usaba MTA; sumber daya manusia, dengan sistem kaderisasi terstruktur; sumber daya sosial-organisasi yang terstruktur baik, dan sumber daya finansial yang luar biasa. Ketiga, menyusun proses gerakan dalam menyelesaikan berbagai penyakit umat dengan solusi yang tepat bagi MTA.
\end{abstract}

Kata Kunci: MTA, gerakan sosial, Purifikasi.

Permalink/DOI: http://dx.doi.org/10.18326/infsl3v12i1.213-238 


\section{Pendahuluan}

Islam puritan adalah kelompok yang gerakannya berseberangan dengan praktik keagamaan umat Islam yang menyatukan prinsipprinsip dasar ajaran Islam dan budaya, tradisi, dan segala hal yang dinilai tidak bersumber pada Al-Qur'an dan Sunnah (Hassan, 2002: 14). Berseberangan di sini disebabkan karena adanya keinginan dari kelompok puritan untuk memberantas adanya praktikpraktik keberagamaan Islam yang bercampur dengan unsur-unsur tradisi lokal. Praktik beragama bercampur tradisi ini kemudian memunculkan praktik keberagamaan baru yang dianggap tidak ada dalam ajaran Islam yang murni seperti yang telah dituntunkan oleh Al-Qur'an dan Hadis, dan hal ini dianggap tidak murni atau bid'ah dan sesat, sehingga patut ditolak.

Dalam mengekspresikan penolakan tersebut, kelompok Islam murni ini mengusulkan pembacaan tunggal terhadap keislaman, yang dianggap sebagai sebuah pembacaan murni, dan dari sinilah kemudian muncul klaim kebenaran tunggal. Jika ada pembacaan lain yang tidak sesuai dengan kebenaran tunggal tersebut, dianggap sebagai hal yang salah, sesat, bid'ah dan bahkan syirik (Muhammadiyah, 1991: 13). Dari sinilah kemudian memunculkan konflik dengan kelompok lain, khususnya dengan kelompok Islam tradisional.

Konflik antara kelompok Islam murni dengan kelompok Islam tradisional ini tergambarkan dengan baik oleh Deliar Noer. Menurutnya, konflik tersebut bisa dilihat dari tiga aspek, yaitu semangat pemurnian ajaran, sikap terhadap tradisi bermazhab, dan sikap terhadap perubahan dan rasionalitas (Noer, 1996). Ketiga hal inilah yang memang mengemuka dalam konstelasi keberagamaan Islam di Indonesia. Apalagi umat Islam Indonesia berdiri di atas berbagai kebudayaan dan tradisi lokal yang memang sudah ada lebih dahulu sebelum Islam masuk ke dalam masyarakat Indonesia.

Fakta tersebut tidak bisa dielakkan, karena bagaimanapun gerakan puritanisme Islam di berbagai negara di mana Islam menjadi bagian di dalamnya, akan selalu berbenturan dengan tradisi lokal. Konflik pasti akan terjadi, mengingat masing-masing pihak, baik 
gerakan puritan Islam maupun tradisi lokal, memiliki kecenderungan konservatif, yaitu melindungi, menjaga dan melestarikan nilai-nilai (values) masing-masing (Asroni, 2013: 214).

Salah satu kelompok puritanis Islam adalah Majelis Tafsir Al-Qur'an (MTA). Seperti kelompok Islam puritan lainnya, MTA mengajak umat Islam untuk kembali kepada Al-Qur'an. Dengan demikian, Al-Qur'an menjadi titik aksentuasi utama dalam semua kegiatan MTA (Sunarwoto, 2012: 138). Dari ajakan ini, MTA memberikan penafsiran terhadap Al-Qur'an secara literer-tekstual dan menolak keras praktik keagamaan yang bercampur dengan tradisi lokal.

Gerakan dakwah MTA ini dilakukan secara keras dan kaku serta disebarluaskan secara frontal. Hal inilah yang memunculkan konflik horizontal antara MTA dengan kelompok tradisional yang memang mempraktikkan sintesis antara ajaran Islam dengan tradisi lokal. Ada banyak kasus konflik antara MTA dengan kelompok tradisional, khususnya NU, seperti yang tergambarkan dalam penelitian Iklila Nur Afida yang dilakukan di Bantul (Afida, 2015), Indriyani Ma'rifah dan Ahmad Asroni di Purworejo (Asroni, 2013: 14), dan M. Alfandi di jantung MTA, Surakarta (Alfandi, 2013: 21).

Meskipun mempraktikkan konsep dakwah yang kaku dan keras serta menuai konflik dengan kelompok tradisional, namun MTA berkembang dengan pesat di Indonesia. Dalam rilis Yayasan MTA tahun 2013, seperti yang dikutip Mustolehuddin, disebutkan bahwa MTA telah memiliki 127 perwakilan setingkat kabupaten/ kota dan 429 cabang setingkat kecamatan yang tersebar dari Sabang hingga Merauke (Mustolehuddin, 2014). Bahkan dalam Silaturahmi Nasional MTA di Istora Senayan Jakarta tahun 2013, acara ini dihadiri Wakil Presiden Boediono dan juga Gubernur DKI Jakarta pada waktu, yaitu Joko Widodo.

Dengan diseminasi cabang MTA di seluruh Indonesia dan pengakuan secara nasional, perkembangan MTA menjadi sangat fenomenal di tengah kontroversi eksistensinya yang eksklusif dan dakwahnya yang frontal. Karena itulah, pertanyaannya adalah 
bagaimana sebenarnya konsep dakwah MTA ini? Bagaimana cara mereka mengembangkan gerakan pemurniannya? Hal inilah yang akan dibahas dalam tulisan ini.

Tujuannya adalah agar mampu memberikan gambaran yang utuh tentang konsep dakwah MTA dan bagaimana cara mereka bergerak dan memobilisasi sumber daya gerakannya serta bagaimana gerakan tersebut mampu mewujudkan cita-cita dan tujuan puritanisme gerakan mereka. Karena itulah, untuk membahas gerakan MTA yang diasumsikan sebagai salah satu gerakan sosial, tulisan ini menganalisisnya dengan menggunakan teori gerakan sosial. Dalam hal ini, sebuah organisasi keagamaan yang aktif bergerak melalui berbagai organ yang dimilikinya dapat dianggap sebagai sebuah gerakan sosial, termasuk MTA. Selain karena sudah terorganisasi dengan baik, MTA juga punya wadah dan saluran gerakan terstruktur dan bergerak secara kolektif. Ada sistem politik gerakan yang terlembaga dengan baik, sehingga merangsang terbentuknya aksi-aksi kolektif dan berbagai bentuk gerakan yang diinginkan (McAdam dkk. (eds.), 1996: 3).

Untuk dapat melakukan aksi gerakan sosial, tipologi gerakan sosialnya Doug McAdam, John D. McCarthy, dan Mayer N. Zald, yakni: memanfaatkan peluang politik (political opportunities), memobilisasi struktur (mobilizing structures), dan melakukan penyusunan proses gerakan (framing process) (McAdam dkk. (eds.), 1996: 2), dapat digunakan untuk menganalisis gerakan MTA ini. Ketiga hal itulah yang menjadi substansi pembahasan dalam membaca gerakan MTA ini.

Dalam hal ini, memobilisasi struktur diarahkan kepada mobilisasi sumber daya MTA dalam melakukan berbagai aksi kolektif untuk bisa memperluas dan memperbesar organisasi dan sekaligus merekrut jamaah baru dengan menggunakan berbagai organnya dan melakukan berbagai aksi kritik terhadap organisasi keagamaan lain. Namun, ketersediaan sumber daya tersebut tidaklah mencukupi, sehingga koordinasi dan usaha strategis dibutuhkan agar bisa mengubah sumber daya yang dimiliki secara individual ke dalam sumber daya kolektif dan memanfaatkan sumber daya 
tersebut untuk kepentingan aksi kolektif (Edward dan McCarthy, 2004: 116). Dengan potensi inilah kemudian teori mobilisasi sumber daya menjadi teori yang cukup dominan dalam menganalisis gerakan sosial dan tindakan kolektif (Buechler, 1995: 441-464).

Apalagi hal ini merujuk pada pendapat David A. Locher bahwa sebuah gerakan sosial itu menunjukkan empat jenis gerakan, yaitu: (1) teori masyarakat massa (mass society theory); (2) teori deprivasi relatif (relative deprivation theory); (3) teori mobilisasi sumber daya (resource mobilization theory); (4) teori proses politik (political process theory) (Locher, 2002: 249-267). Teori mobilisasi sumber daya inilah yang dipakai dalam konteks memobilisasi struktur dalam pandangan Doug McAdam, John D. McCarthy, dan Mayer N. Zald di atas.

Dalam kaitan tersebut, memobilisasi sumber daya itu bisa dilihat dari lima mobilisasi sumber daya, yaitu sumber daya moral, sumber daya kultural, sumber daya sosial-organisasional, sumber daya manusia, dan sumber daya materi (Edward dan McCarthy: 125). Seperti yang akan dijelaskan nanti, mobilisasi berbagai sumber daya inilah yang menjadi motor penggerak dari gerakan MTA dalam melakukan purifikasi keagamaan.

Sedangkan dalam proses framing, menurut Snow dan Benford (1998: 197-217), ada tiga kunci pokok dalam analisisnya, yaitu diagnostik, prognostik, dan motivasi. Diagnostik adalah proses identifikasi permasalahan oleh suatu gerakan sosial dan attribusi faktor atau pihak-pihak yang dianggap bersalah dalam permasalahan tersebut. Misalnya, peneliti mencari apa atau keadaan apa yang dianggap salah oleh MTA, dan kemudian siapa yang dianggap bersalah dalam permasalahan tersebut. Prognostik adalah proses pencarian solusi terhadap problem, dan penentuan strategi, taktik, dan target. Misalnya, peneliti akan melihat strategi apa yang MTA terapkan untuk memperbaiki keadaan atau permasalahan tersebut. Motivasi adalah proses pencapaian aksi sesuai dengan diagnostik dan prognostik. Misalnya peneliti menganalisis cara apa yang mereka lakukan agar anggota MTA dan pendukung lainnya turut 
berpartisipasi dalam melaksanakan strategi tersebut. Jadi, tiga aspek inilah yang dijadikan acuan untuk menganalisis gerakan MTA.

\section{Metode Penelitian}

Penelitian ini merupakan penelitian kualitatif yang sumber penelitiannya dikumpulkan melalui kajian pustaka dan kerja lapangan yang dianalisis dengan menggunakan perspektif sosiologis, yaitu teori gerakan sosial. Teori gerakan sosial digunakan untuk menganalisis gerakan puritan MTA mulai dari cara MTA memanfaatkan peluang politik (Political Opportunity), memobilisasi lima sumber daya dan melakukan framing process.

Sedangkan teknik pengumpulan data lapangan yang digunakan adalah observasi dan wawancara mendalam (depth interview). Pengamatan dilakukan untuk mengamati aktivitasaktivitas yang dilakukan oleh MTA sebagai sebuah organisasi dengan mengikuti beberapa kegiatan yang dilakukan oleh MTA seperti pengajian gelombang, donor darah, dan sebagainya. Sedangkan wawancara mendalam dilakukan terhadap para pengurus MTA baik pengurus pusat maupun pengurus daerah. Wawancara juga dilakukan kepada mantan warga MTA yang pernah bergabung dengan MTA lebih dari 20 tahun. Selain observasi dan wawancara, peneliti juga mempelajari berbagai buku, artikel, laporan penelitian, berbagai penelitian akademis yang berkaitan dengan MTA

Dalam pengumpulan data, besar kemungkinan terjadi distorsi data. Untuk mengeliminasi ketidaksahihan data, dilakukan kritik dengan cara crosscheck data. Hal ini dilakukan dengan mencocokkan hasil wawancara antara informan yang satu dengan informan lainnya dan antara hasil wawancara dengan hasil observasi dan studi pustaka. Dari crosscheck data ini kemudian dianalisis data mana yang mempunyai akurasi kebenaran paling tinggi.

Langkah-langkah analisis datanya adalah dengan melakukan kategorisasi dan kodifikasi data-data, mereduksi data-data, mendisplay, membuat verifikasi dan kesimpulan (Moehadjir, 1989). Analisis juga dilakukan dengan menggunakan teori gerakan sosial. 


\section{Pembahasan}

\section{Profil Majlis Tafsir Al-Qur'an (MTA)}

Majelis Tafsir Al-Quran atau disingkat MTA adalah lembaga dakwah dalam bentuk yayasan yang didirikan oleh seorang mubalig keturunan Pakistan yang berprofesi sebagai pedagang yang bernama Al-Ustadz Abdullah Thufail Saputra pada tanggal 19 September 1972. Pendirian Yayasan MTA ini selanjutnya dikukuhkan dengan akte notaris R. Soegondo Notodisoerjo, nomor 23, tanggal 23 Januari 1974 di Surakarta. Ia mendirikan dan memimpin MTA 1972-1992. Kini MTA dipimpin oleh Ahmad Sukina dari tahun 1992 sampai sekarang (Wikipedia).

Ustadz Abdullah Thufail Saputra adalah seorang pedagang batu permata. Dengan profesinya, ia mengelilingi seluruh Indonesia, kecuali Irian Jaya. Ia juga seorang yang berjiwa dakwah. Ia pernah menjadi Dewan Dakwah Nusa Tenggara Timur. Dalam perdagangan, ia selalu menyempatkan diri untuk membaca buku. Melihat umat Islam Indonesia yang jauh dari Al-Qur'an dan As-Sunnah serta banyaknya perselisihan yang terjadi antara sesama umat Islam ini, ia sangat prihatin dengan keadaan umat Islam, hingga akhirnya ia memutuskan untuk menetap di kota Surakarta dan berhenti dari profesinya sebagai pedagang. Kemudian, ia mendirikan Majlis Tafsir Al-Qur'an (MTA) yang mengonsentrasikan kegiatannya pada ide-ide pemurnian Islam dari elemen-elemen lokal dan berupaya menghindar dari bentrokan langsung dengan kebijakan negara (Zuhri, 2009: 291-292).

Awalnya, kajian MTA dilakukan di Masjid Marwah kelurahan Semanggi. Pesertanya hanya warga di sekitar Semanggi, dan beberapa orang dari wilayah sekitar Solo. Perkembangan MTA cukup pesat, terlihat dari berdirinya cabang-cabang di beberapa daerah lain, seperti di Kecamatan Nogosari (Boyolali), Kecamatan Polan Harjo dan Kecamatan Juwiring (Klaten), dan di Kecamatan Gemolong (Sragen). Perkembangan berikutnya penyebaran MTA dilakukan oleh siswa-siswa yang sudah nyantri di MTA Pusat maupun di cabang-cabang. Mereka membentuk kelompok-kelompok pengajian di daerah asalnya atau di perantauan. Mereka memiliki 
tanggungjawab dan kesadaran untuk menyebarkan ilmu walaupun tidak diinstruksikan. Setelah menjadi besar, kelompok-kelompok pengajian itu mengajukan permohonan ke MTA Pusat agar dikirimi guru pengajar sehingga kelompok-kelompok pengajian itu pun menjadi cabang-cabang MTA yang baru. Dengan cara itu, tumbuh cabang-cabang baru.

Ketika di satu kabupaten sudah tumbuh lebih dari satu cabang dan diperlukan koordinasi, dibentuklah perwakilan yang mengoordinasi cabang-cabang tersebut yang bertanggung jawab membina kelompok-kelompok baru sehingga menjadi cabang. MTA Pusat tidak pernah menggunakan strategi top down dalam membentuk dan meresmikan perwakilan dan cabang, tapi secara buttom up (Ariyanto, 2010: 60). Dengan cara itu, banyak terbentuk cabang-cabang dan perwakilan-perwakilan baru, sehingga pada Silatnas III MTA di Surakarta, diresmikan lebih dari 600 cabang dan perwakilan MTA di seluruh Indonesia.

\section{Doktrin Teologi Majlis Tafsir Al-Qur'an (MTA)}

Dengan menyebar dan banyaknya cabang dan perwakilan MTA di seluruh Indonesia, pada dasarnya dakwah yang dilakukan MTA ini dapat dikatakan berhasil dengan baik. Hal ini mencakup tiga hal esensial gerakan, yaitu tauhid dan syirik, bid'ah, dan kembali pada Al-Qur'an dan sunnah (Zuhri, 2009: 291-292).

Pertama, tauhid dan syirik. Inti tauhid yang selalu ditekankan oleh MTA adalah pemurnian Islam dari ritual yang dianggap bertentangan dengan Islam atau antitesa dari tauhid itu sendiri: syirik. Tauhid didefinisikan sebagai sikap ketergantungan kepada Allah dan hanya Allah saja tempat meminta, yang kebalikannya adalah meminta kepada selain Allah atau syirik. Guna mencapai kesempurnaan tauhid, MTA beranggapan bahwa satu-satunya sumber tauhid yang bisa diterima adalah Al-Qur'an dan sunnah, bukan tradisi (Zuhri, 2009: 292).

Sikap tauhid ini selalu dibenturkan dengan tradisi masyarakat Jawa yang bagi Sukina sudah jauh melenceng dari ajaran Islam. 
Sukina menyebutkan bahwa tradisi padusan, slametan, suronan yang kerap dilaksanakan tidak hanya oleh orang Jawa, namun juga umat Islam, merupakan bukti nyata bahwa Islam sudah terkontaminasi oleh ajaran yang menyimpang dan menyebabkan mereka jatuh pada kemusyrikan. Untuk menyelamatkan dari kemusyrikan, umat muslim, menurut Sukina, perlu mengevaluasi ulang sikap keberagamaan mereka, apakah sudah sasuai dengan ajaran Al-Qur'an dan sunnah ataukah tidak.

Namun, meski menghimbau umat menghindari elemenelemen lokal atau non-Islam serta melarang kegiatan-kegiatan tasawuf dan tradisi Islam Jawa, MTA memperbolehkan anggotanya untuk belajar dan memainkan gamelan dan wayang. Dia mengajarkan bahwa benda-benda pusaka tersebut sama sekali tidak memiliki kekuatan magis/spiritual, meski tanpa harus menghancurkan bendabenda tersebut. Di sini, Sukina berpandangan bahwa benda-benda tersebut tidak akan merusak iman umat, sepanjang cukup dianggap sebagai benda mati saja, tanpa pernah dilabeli dengan keyakinan (Zuhri, 2009: 293-294).

Untuk menyikapi budaya lokal yang berkembang di masyarakat, MTA memiliki tiga pendekatan. Pertama, budaya lokal yang sejalan dengan Al-Qur'an dan Sunnah akan biarkan. Kedua, kalau budaya itu perlu diluruskan, akan diluruskan. Ketiga, budaya lokal yang berlawanan dengan ajaran Islam, harus ditolak sama sekali.

Kedua, bid'ah. Menurut MTA, bid'ah berarti "penambahan" atau "yang baru", dan merupakan lawan dari sunnah (tradisi yang hidup) dalam persoalan ibadah. Konsekwensi jika melaksanakan ibadah adalah ditolaknya amal ibadah seseorang dan juga dapat merusak amal ibadah yang lain. Bahkan, Sukina beranggapan bahwa ritual-ritual bid'ah mengandung unsur yang menyebabkan kemusyrikan. Terlebih lagi pada masa sekarang, sehingga ajaran Islam harus dibersihkan, tidak hanya dari elemen-elemen lokal saja, tapi juga dari berbagai pengaruh Barat, seperti perayaan tahun baru dan valentine day yang kerap dirayakan oleh umat muslim sendiri (Zuhri, 2009: 295-296). 
Ketiga, kembali pada Al-Qur'an dan Sunnah. Sama seperti kebanyakan umat muslim, MTA beranggapan bahwa Al-Qur'an menjadi sumber utama dalam memahami Islam dan sunnah sebagai sumber kedua. Sukina menekankan perlunya pemahaman secara individual terhadap teks-teks Al-Qur'an dan sunnah. Baginya, mengetahui dan memahami teks sangatlah perlu agar umat Islam tidak terjerumus dalam taklid, tapi harus berperilaku ittiba', yakni mengetahui setiap dalil Al-Qur'an dan Sunnah, dan hal ini jelas tergambar dalam setiap pertemuan pengajian MTA. Brosur-brosur yang dibagikan kepada peserta hanya berisi kutipan-kutipan AlQur'an dan Sunnah, tanpa ada penjelasan apapun. Satu-satunya penjelasan adalah melalui ceramah-ceramah Sukina (Zuhri, 2009: 294).

Dalam memahami Al-Qur'an dan Sunnah, MTA menekankan kongruensi dan paralelitas dalil. Oleh karena itu, pemahaman MTA sangatlah skripturalistik yang hanya berorientasi pada teks. Kajian yang diangkat bukan kajian kronologis ayat, namun pada kajian tematik. Selain itu, sentralitas teks ini berimplikasi langsung terhadap cara pandang MTA terhadap Al-Qur'an dan Sunnah, utamanya Sukina yang menjadi interpretator. MTA selalu menekankan bahwa teks Al-Qur'an tidak perlu dipertanyakan kebenarannya dan di sana setiap umat Islam bisa menemukan dalil yang berisi aturan bagaimana umat Islam harus bersikap, berfikir dan bertindak. Bahkan, dalam banyak kesempatan, Sukina, ketika merespon pertanyaan-pertanyaan menyangkut hukum Islam ( $f i q b$ ), hanya terfokus pada dalil-dalil tersebut. Dengan demikian, Al-Qur'an dan Sunnah cenderung dipandang sebagai kitab hukum bagi umat Islam, ketimbang sebagai kumpulan prinsip ajaran Islam yang bersifat universal, di mana setiap orang mampu melaksanakan deduksi hukum.

\section{Gerakan Sosial Islam Puritan Majlis Tafsir Al-Qur'an (MTA)}

MTA berdakwah dengan intens, kontinual, terstruktur, dan sistematis. Hal ini disebabkan karena mereka memiliki berbagai organ yang bergerak dengan efektif yang secara berjamaah mendukung kegiatan dakwah mereka. Karena itulah, mereka 
dianggap sebagai bagian dari gerakan sosial. Hal ini dapat dilihat dari tiga aspek gerakan sosial, yaitu memanfaatkan peluang politik, memobilisasi berbagai sumber daya, dan menyusun proses gerakan (framing process).

\section{Memanfaatkan Peluang Politik}

Menurut salah satu pengurus MTA Cabang Sukolilo Surabaya, Hasan Ikhwani, MTA itu adalah suatu majlis untuk mempelajari tafsir Al-Qur'an, bukan untuk menafsirkan Al-Qur'an, dan bukan pula mencetak mufassir, serta bukan berusaha membuat dan menyusun kitab tafsir tersendiri. Penekanan kajian tafsir di MTA adalah mengkaji semua kitab tafsir yang ada (salaf/khalaf) untuk dimengerti, dipahami, lalu dihayati, dan kemudian diamalkan dalam praktik kehidupan sehari-hari (Ikhwani, 2017).

Namun, menurut Sunarwoto, MTA melakukan penafsiran sendiri, dan hal itu terbukti dengan terbitnya 5 jilid tafsir MTA (Sunarwoto, 2012: 118-130). Bahkan Sunarwoto menambahkan bahwa realitas yang terjadi di lapangan adalah bahwa dalam pengajian-pengajian yang diadakan MTA, terutama Pengajian Abad Pagi, hampir tidak pernah mengutip atau menyebut penafsiran ulama ahli tafsir. Bahkan dalam pengamatan Sunarwoto, yang sering terjadi adalah penyebutan berbagai catatan kaki (notes) dari terjemahan Al-Qur'an versi Departemen Agama untuk menjelaskan suatu maksud ayat atau kata dalam ayat tertentu yang dipandang musykil (Sunarwoto, 2012: 109-110). Tidak jarang juga hanya dengan penalaran dan penafsiran Sukina sebagai interpretator.

Dari sinilah terlihat ada kamuflase gerakan di mana secara publikasi MTA merupakan wadah untuk mengkaji berbagai penafsiran terhadap Al-Qur'an, seperti penuturan Hasan Ikhwani, yaitu merujuk pada kitab tafsir Ibnu Katsir, al-Maraghi, al-Qurthubi, al-Thobary, fi dhilalil Qur'an, dan sebagainya (Ikhwani, 2017). Padahal senyatanya, dalam setiap pengajian, mereka hampir tidak pernah merujuk kitab tafsir seperti itu. Dengan kondisi seperti ini, ada proses untuk melakukan mobilisasi gerakan dengan memanfaatkan peluang politik, yakni politik pencitraan gerakan. 
Dari proses tersebut, pada dasarnya ada kamuflase yang tujuannya adalah bagaimana menciptakan image yang baik agar bisa meningkatkan akses (increasing access) dan kemudian menciptakan sekutu-sekutu yang berpengaruh (influential allies) (Tarrow, 1998: 71-90). Dengan citra baik, kesan eksklusif dan kontroversial yang dihembuskan lawan-lawan gerakan teredamkan. Apalagi MTA mampu mendatangkan para tokoh berpengaruh di negeri ini, sehingga memberi kesan yang sangat positif terhadap keberadaan MTA. Susilo Bambang Yudoyono (presiden pada waktu itu) hadir melakukan peresmian gedung pusat baru nan megah MTA pada 8 Maret 2009 (mta.or.id, 2017). Tidak hanya itu, kajian Ahad pagi yang menjadi rutinitas kajian MTA, juga menjadi ajang pencitraan dan menciptakan ruang politik yang lebih luas. Kajian Ahad pagi ini diisi oleh pembina MTA, yaitu Ahmad Sukina. Namun, untuk membangun citra positif, kajian Ahad pagi ini juga diisi tokohtokoh agama dari organisasi Islam lain, seperti Dien Syamsuddin, Nasaruddin Umar, Amien Rais, Hatta Rajasa, M.S. Kaban, M. Roem Rowi, Gatot Nurmantyo, Anton Tabah, KH Ridwan Kholil, KH Amidan, dan tokoh-tokoh nasional lainnya baik dari ormas, parpol, MUI Pusat maupun aparat pemerintah (Ikhwani, 2017).

Selain itu, MTA juga membuat dan menyebarkan berbagai peluang (Tarrow, 1998: 71-90), yakni memperluas peluang-peluang yang lain dan menciptakan peluang bagi terciptanya legitimasi yang lebih luas akan eksistensinya. Hal ini dilakukan dengan membentuk acara silaturahmi yang bertaraf nasional yang pada 17 September 2017 yang lalu menyelenggarakan Silaturahmi Nasional III yang dihadiri Presiden Joko Widodo dan Ketua MPR Zulkifli Hasan, serta dihadiri Gubernur Jawa Tengah, Ganjar Pranowo (Wawancara dengan Yoyok pada tanggal 21 September 2017). Dari silatnas inilah kemudian ada semacam mobilisasi peluang politik MTA, sehingga MTA memiliki kekuatan politik yang baik untuk bisa menancapkan eksistensinya di negeri ini. Hal ini juga membungkam berbagai tuduhan miring yang dialamatkan kepada MTA sebagai kelompok yang kontroversial dan eksklusif.

Selain itu, Ahmad Sukina menegaskan bahwa MTA bukan partai politik dan tidak akan pernah menjadi partai politik, bukan suatu golongan dan tidak akan menjadi tersendiri dari umat 
Islam (Sukino, 2008: 104). Namun, dalam praktiknya, MTA juga memberikan dukungan kepada salah satu faksi politik tertentu, dan hal itu juga dilakukan secara eksklusif untuk dikonsolidasikan secara internal dan "rahasia". Hal ini terutama dilakukan pada saat koordinasi mingguan pasca Kajian Ahad Pagi, waktu di mana para pengurus MTA seluruh Indonesia berkumpul membahas berbagai permasalahan yang terjadi di Ahad siangnya. Hal inilah yang dikemukakan salah satu informan yang merupakan mantan anggota MTA (Wawancara dengan Irw pada tanggal 23 November 2017).

\section{Memobilisasi Sumber Daya}

Sumber daya di sini meliputi: pertama, sumber daya moral atau sumber legitimasi gerakan. Legitimasi paling substansial dari gerakan MTA adalah pada misi mereka, yaitu melakukan purifikasi terhadap cara beragama masyarakat Jawa yang mempraktikkan TBC (takhayul, bid'ah, dan churafat), mirip seperti apa yang dilakukan Muhammadiyah (Wildan, 2009: 87). Semangatnya adalah kembali kepada Al-Qur'an dan Sunnah. Karena itulah, legitimasi moral yang paling utama adalah Al-Qur'an dan Sunnah tersebut. Bagi Abdullah Thufail, kondisi umat Islam tersebut akan bisa diperbaiki tak lain jika mereka mau kembali kepada Al-Qur'an (Asif, 2015: 31). Kembali pada Al-Qur'an ini dilakukan dengan tegas dan tanpa kompromi, bukan seperti yang dilakukan Muhammadiyah, yang dianggap terlalu lemah menerapkan doktrin-doktrin Islam (Wildan, 2009: 50).

Dalam hal kembali kepada Al-Qur'an dan Sunnah, MTA menggunakan ijtihad. Namun, ijtihad hanya boleh dilakukan oleh orang yang memenuhi persyaratan. Di dalam MTA, yang berhak melakukan ijtihad adalah sang imam, yakni pemimpin MTA. Sedangkan ustadz-ustadz dan warga MTA ataupun Muslim awam tidak diperbolehkan ijtihad (Jinan, 2013: 592). Namun mereka wajib ittiba' (mengikut). Yang dilarang menurut MTA adalah sikap taklid, yakni mengikuti amalan-amalan agama atau ibadah dengan tanpa tahu dalil-dalilnya. Di kalangan warga MTA, orang yang taklid adalah orang yang cara beragamanya, dalam bahasa Jawa, rububrubub gedang, yang berarti ikut-ikutan nenek-moyang dan orang tua terdahulu. Untuk bebas dari taklid, orang harus tahu dalil atau 
"tuntunan" dari Al-Qur'an dan Sunnah. Untuk itu, orang harus ngaji atau mengkaji Al-Qur'an dan Sunnah (Sunarwoto, 2012: 110). Dengan demikian, sumber legitimasi moral selanjutnya adalah figur atau tokoh MTA itu sendiri.

Kedua, memobilisasi sumber daya kultural. Mobilisasi sumber daya kultural MTA ini terkait mobilisasi amal usaha yang dimiliki MTA dalam rangka melakukan pembinaan struktural dan anggota MTA sehingga mesin gerakan MTA ini akan terus bergerak dan berproses menuju pada tujuannya. Mobilisasi sumber daya kultural ini lebih banyak terasa pada masa kepemimpinan Sukina, mengingat pada masanya itulah MTA mencapai progres yang luar biasa.

Pada masa kepemimpinan Sukina, tahap perkembangan MTA dapat dibagi menjadi dua bagian, yaitu tahap pemantapan dan perluasan. Pertama, tahap pemantapan adalah tahap di mana MTA memantapkan diri sebagai gerakan yang terbuka dengan melanjutkan berbagai amal usaha seperti sekolah, jaringan bisnis, penerbitan, dan Balai Pengobatan. Kedua, tahap perluasan ditandai dengan hadirnya media komunikasi internet, radio MT@-FM, dan TV-MTA. Bahkan dapat dikatakan dakwahnya pada periode kepemimpinan Sukina dapat dilihat pada sebelum adanya dan sesudah radio. Gerakan ini memanfaatkan internet, radio, dan televisi (Jinan, 2013: 114-115).

Ketiga, mobilisasi sumber daya sosial organisasional. Dalam hal ini, struktur organisasi MTA disusun dengan jenjang yang terstruktur dan terorganisasikan dengan baik. Menurut Yoyok, struktur organisasi di MTA itu terdiri dari tiga struktur, yaitu: (1) MTA pusat, yang berkedudukan di Surakarta. (2) MTA Perwakilan yang berkedudukan di tingkat kabupaten/kota. (3) MTA Cabang yang berkedudukan di tingkat kecamatan. Setiap pengurus pusat, perwakilan, dan cabang itu memiliki pengurus tersendiri (Wawancara dengan Yoyok, 21 September 2017).

Karena MTA sebenarnya adalah sebuah yayasan, dan bukan organisasi sosial, maka organisasi MTA dilaksanakan berdasarkan UU Yayasan. Di Yayasan ada tiga unsur, yaitu pembina, pengurus dan pengawas. Pembinanya hanya satu, yaitu Ustadz Ahmad Sukina, sedangkan pengawasnya tidak berfungsi. Pengurusnya terdiri 
dari: ketua umum, ketua, sekretaris umum, sekretaris, bendahara umum, dan bendahara. Mereka dibantu dengan berbagai seksi yang menggerakkan gerakan dakwah MTA.

Dalam memobilisasi sosial-organisasinya, Ahmad Sukina menjadikan MTA beralih dari memfokuskan diri pada pengajaran keagamaan menjadi semacam ormas Islam layaknya ormas-ormas lain, meskipun pada kenyataannya mereka tidak mengklaim diri sebagai ormas, tetapi yayasan. Karena itulah, di samping wilayah dakwah dan pengajaran, MTA memperlebar sayap ke wilayah pendidikan, siaran, kesehatan, penerbitan, dan juga sosial (Asif, 2015: 29).

Untuk mendukung gerak organisasional tersebut, MTA Pusat dibantu MTA Perwakilan yang ada di tingkatan kabupaten/ kotamadya dan MTA Cabang yang mewakili tingkat kecamatan. Setiap perwakilan dan cabang memiliki pengurusnya sendirisendiri yang minimal terdiri dari ketua, sekretaris, dan bendahara serta beberapa seksi. Dalam hal pelantikan pengurus di tingkatan Perwakilan dan Cabang, sebelum silatnas diadakan, pelantikannya langsung di daerah. Jadi, pengurus pusat yang melantik datang ke daerah untuk melantik pengurus perwakilan dan cabang. Karena ketika pelantikan di daerah banyak kendala, sejak 2013 pelantikan perwakilan dan cabang dijadikan satu dalam ajang silaturahmi nasional (silatnas) (Wawancara dengan Yoyok, 21 September 2017).

Selain itu, untuk memobilisasi sumber daya sosial-organisasi, MTA juga mengadakan Kajian Ahad Pagi atau yang bisa disebut sebagai Jihad Pagi, dari pukul 7.30 hingga 11.00 di Gedung MTA Jl. Ronggowarsito No. 111 A Surakarta. Pengajian ini dihadiri ribuan orang dan merupakan hal biasa, tapi yang menjadi penting adalah mobilisasi yang dilakukan paska kajian ahad pagi tersebut, yaitu di siang harinya, di mana pengurus seluruh Indonesia atau yang mewakilinya hadir melakukan konsolidasi setiap minggunya dan membahas berbagai hal terkait gerakan MTA.

Keempat, memobilisasi sumber daya manusia. MTA melakukan pembinaan yang mirip dengan organisasi kader. Ada lima tingkatan anggota MTA (Wawancara dengan Irw, 23 November 2017), yaitu: (1) Simpatisan. Mereka adalah orang yang suka menghadiri kajian 
Ahad pagi dan radio MTA tapi belum terikat dengan MTA. (2) Mustami'. Mereka adalah orang yang sudah ikut mengaji di cabangcabang atau pengajian gelombang, tapi belum menjadi siswa MTA. (3) Siswa (anggota MTA) di tingkatan cabang. Siswa ini sudah mengisi formulir dan sudah diabsen pada saat pengajian. Hal ini berbeda dengan mustami' yang belum terdaftar, karena memang belum menjadi anggota resmi. (4) Anggota khusus. Mereka adalah siswa MTA yang sudah mendapatkan perlakuan khusus dan harus mengikuti pengajian khusus dengan materi-materi khusus. Agar dapat menjadi anggota khusus, santri harus mengalami proses baiat. Mekanismenya: Dari cabang direkomendasikan ketua cabang, lalu direkomendasikan dengan membawa surat pengantar ke pusat, dan ketika diterima kemudian mendapatkan pendidikan dan latihan serta pembinaan secara khusus selama 3-6 bulan. Setelah selesai ada pengantar berikutnya yang menyatakan jika dia sudah selesai. Lalu pengantar berikutnya ikut kajian khusus seminggu sekali hingga 12 kali. Jika sudah tidak bermasalah, proses baiat dapat dilakukan. Anggota khusus punya kewajiban: (a) Harus mengikuti pengajian gelombang khusus; (b) mengikuti pertemuan kelompok khusus; (c) tetap mengikuti pengajian gelombang anggota biasa; (d) mengikuti pertemuan kelompok anggota biasa; (e) wajib mengisi pengajian gelombang di tempat tugasnya sesuai instruksi Sukina. (5) Anggota khususi khusus (ansharullab). Anggota khususi khusus ini adalah anggota yang paling istimewa, dan agar bisa masuk ke sana akan melewati baiat khusus lagi. Tentu saja tidak sembarang orang bisa masuk menjadi anggota khususi khusus ini, sehingga dapat dikatakan bahwa ini adalah anggota elite MTA.

Dari lima bentuk di atas, dapat dilihat bahwa proses menjadi anggota MTA ini sangatlah terstruktur, persis seperti kaderisasi Jamaah Tarbiyah dan Hizbut Tahrir (Muhsin, 2015). Dari pembahasan di atas, dapat disarikan bahwa untuk menjadi anggota MTA harus melalui tiga tahapan, yaitu tahap pengenalan, tahap pembinaan, dan tahap pemantapan (Jinan, 2013: 115).

Dari tiga tahapan tersebut, pada dasarnya yang menjadi inti adalah pengajian yang diselenggarakan MTA. Dalam hal ini, ada lima bentuk pengajian di MTA (Wawancara dengan Yoyok pada tanggal 21 September 2017), yaitu: pertama, pengajian gelombang. 
Pengajian gelombang ini dilakukan baik di pusat, perwakilan, dan juga cabang. Pengajian ini diadakan satu minggu sekali dan berlangsung sekitar 3 jam. Pengajian ini menjadi wajib bagi anggota MTA dan menjadi inti pengajian MTA. Satu cabang bisa lebih dari satu pengajian gelombang, tergantung jumlah anggota. Jika warga MTA tidak menghadiri pengajian gelombang tiga kali berturut-turut tanpa izin, yang bersangkutan akan dikeluarkan dari keanggotaan MTA. Kedua, pengajian kelompok. Pengajian kelompok adalah pengajian gelombang yang dipecah menjadi kelompok yang lebih kecil. Sebagai gambaran, pengajian gelombang di kantor perwakilan Salatiga memiliki sekitar 150 warga MTA. Dari 150 warga MTA tersebut dibagi menjadi 7 kelompok kecil, yang jumlah jamaahnya disesuaikan dengan tempat tinggal masing-masing anggota. Pengajian ini juga diadakan seminggu sekali (Wawancara dengan Tontowi pada tanggal 22 Oktober 2017). Fungsi pengajian kelompok ini adalah: (1) pendalaman materi gelombang sebelumnya; (2) taaruf antar anggota di kelompok terkait berbagai aspek kehidupan anggota; (3) taawun dalam semua hal terkait dengan kehidupan anggota kelompok. Jika tidak bisa diselesaikan di kelompok, lalu akan dibawa ke pengajian gelombang. Jika tidak bisa dipecahkan di tingkatan gelombang, akan dibawa ke MTA Pusat pada saat pertemuan bakda kajian Ahad Pagi (Wawancara dengan Sadono pada tanggal 22 Oktober 2017). Ketiga, pengajian Ahad pagi atau pengajian umum dan terbuka untuk siapa saja. Keempat, pengajian nafar fi sabilillah. Pengajian ini merupakan kegiatan perjalanan dakwah yang diselenggarakan oleh MTA setahun sekali pada bulan Ramadhan (Wawancara dengan Yoyok, 21 September 2017).

Dari berbagai pengajian tersebut, yang paling vital adalah ustad yang mengisi pengajian-pengajian tersebut. Ada dua jenis ustad yang diakui MTA, yaitu: pertama, ustad tingkat pusat atau pembina, yaitu Ustad Ahmad Sukina. Ia mengajar pada pengajian Ahad pagi dan pengajian gelombang khususi. Ia menjadi penceramah tunggal dalam kedua pengajian tersebut. Selain bertindak sebagai pengajar pada pengajian umum dan pengajian gelombang khususi, ia juga dijadikan sebagai sosok untuk memecahkan permasalahan hidup warga MTA ketika mereka menghadap dan mengonsultasikannya (Yulyastyika, 2011: 59-60). 
Kedua, ustad perwakilan atau cabang. Ustadz pada tingkat ini disebut juga guru daerah yang jumlahnya cukup banyak. Mereka mengajar pengajian pada pengajian perwakilan atau cabang MTA. Bagi setiap guru daerah, wajib memberikan ceramah pengajian secara rutin di daerah yang sudah ditunjuk pengurus MTA pusat (Yulyastyika, 2011: 60). Menurut Yoyok, Ada pertemuan guruguru daerah setiap dua minggu sekali. Pertemuan ini merupakan koordinasi untuk penugasan guru-guru ke berbagai perwakilan dan cabang, juga membahas masalah-masalah yang timbul di daerah (Wawancara dengan Yoyok, 21 September 2017).

Kelima, memobilisasi sumber daya material (finansial). Pada dasarnya dana MTA ini dikelola secara mandiri, dengan cara: pertama, zakat. Anggota MTA wajib menunaikan zakat dan diserahkan ke pusat. Haul dan nishab tidak dikenal. Semua penghasilan harus dizakati $2,5 \%$. Caranya melalui pengajian gelombang dari pengurus cabang, ke perwakilan, dan kemudian bisa dibawa ke pusat. Kedua, insidental. Gedung MTA pusat dibangun murni swadaya warga MTA meski menghabiskan dana 13 miliar dan hanya jangka waktu setahun sudah berdiri bangunan 4 lantai (Wawancara dengan Irw, 23 November 2017).

Selain itu, dalam melaksanakan aktivitas dakwahnya, warga MTA tidak boleh mengajukan proposal atau meminta bantuan kepada pihak lain dalam bentuk apa pun. Menurut Yoyok (Wawancara dengan Yoyok, 21 September 2017):

"Kita tidak boleh mengajukan proposal minta bantuan.

Kita harus Infiruu khifaafa wa siqaala wa jaabiduu bi amwaalikum wa anfusikum fi sabiilillah. Dzaalikum khairul lakum in kuntum ta'lamuun (Berangkatlah kamu baik dalam keadaan merasa ringan maupun berat, dan berjihadlah kamu dengan harta dan dirimu di jalan Allah. Yang demikian itu adalah lebih baik bagimu, jika kamu mengetahui). Itu yang harus kita pahami dan kita amalkan. Pada zaman nabi kan gitu. Pada zaman nabi dan sahabat perang kan beli senjata sendiri. Namun, MTA tidak menolak jika ada pihak lain memberikan dananya kepada kegiatan dakwah MTA. Seperti pemerintah yang memberikan dana BOS kepada sekolah-sekolah MTA.” 
Menyusun Proses Gerakan (Framing Process)

Dalam proses framing, MTA bergerak dalam tiga koridor purifikasi keberagamaan Islam. Pertama, MTA melakukan diagnosa atau identifikasi terhadap masalah yang terjadi pada umat. Ada tiga hal yang menjadi sorotan, yaitu tauhid dan syirik, bid'ah, dan kembali pada Al-Qur'an dan sunnah. Menurut Sukina, tradisi padusan, slametan, dan suronan yang kerap dilaksanakan sudah menyimpang dan menyebabkan mereka jatuh pada kemusyrikan. Selain itu, ritual-ritual bid'ah yang tidak ada tuntunannya dalam Al-Qur'an dan Hadis Nabi Saw juga mengandung unsur yang menyebabkan kemusyrikan, dan hal ini harus ditolak. Karena itu, umat harus kembali kepada Al-Qur'an dan Hadis serta mengetahui dan memahami teks-teks tersebut agar umat Islam tidak terjerumus dalam taklid. Namun demikian, umat harus berperilaku ittiba' kepada yang diyakini mampu untuk memberikan pemahaman dan pengetahuan akan Al-Qur'an dan Hadis.

Kedua, MTA mencari prognostik dari diagnosa yang ada, sehingga dapat dicarikan solusi terhadap permasalahan yang terjadi. Dalam proses ini, MTA dalam setiap kajiannya selalu menentang praktik-praktik menyimpang yang dilakukan umat Islam. Mereka melakukannya secara frontal dan bahkan menyerang kelompokkelompok yang melakukan praktik-praktik tersebut dengan menyebutnya sebagai bid'ah atau bahkan kafir. Karena itulah, dalam proses ini, MTA selalu vis-a-vis dengan kelompok penentangnya. Hal ini pula yang menyebabkan MTA juga balik mendapatkan stigma sebagai kelompok radikal dan bahkan dianggap sebagai kelompok yang menyimpang. Selain itu, dalam setiap kajian yang dilakukan, MTA selalu memberikan solusi terhadap permasalahan umat dengan menafsirkan sendiri terhadap Al-Qur'an dan Hadis berdasarkan pemahaman pemimpinnya. Tidak hanya memberikan solusi, MTA juga selalu mengingatkan umat Islam untuk selalu menjauhi sumber penyakit umat Islam tersebut. Karena itu, anggota MTA harus ittiba' terhadap penafsiran pemimpinnya yang dianggap sebagai kebenaran yang mutlak. 
Dalam kaitan ini, Ahmad Sukina menegaskan bahwa,

"Sebaik-baiknya perkataan adalah kitab Allah, yaitu Al-Qur'an, dan sebaik-baiknya petunjuk adalah petunjuk dari Rasulullah. Sejelek-jeleknya urusan atau perkara adalah perkara yang diada-adakan, yang pada zaman nabi dan zaman sahabat tidak pernah ada. Perkara yang diadaadakan dan semua yang diadakan itu adalah bid'ah. Semua bidah itu sesat dan semua yang sesat itu masuk neraka. Maka dari itu dalam urusan ibadah kita jangan membuat aturan sendiri, terus bayangan pahalanya dibuat sendiri. Jika semua praktik keagamaan itu tidak ada tuntunannya dari Rasulullah, maka itu adalah termasuk syarrul umuur, sejelek-jeleknya perkara (Sukina, 2008: 38).

Sukina juga menegaskan bahwa seseorang yang beribadah seharusnya memahami dengan benar apa dasar atau dalil yang dijadikan landasan dalam beribadah. Kalau tidak mengetahui dalilnya, jangan pernah melakukan ibadah tersebut. Sebab hal itu akan sia-sia. Jadi, dalam hal ibadah ojo takon larangan tetapi takono tuntunane (Khalim, 2016: 65).

Ketiga, agar dapat memperkuat pemahaman, setiap anggota MTA wajib mengikuti kajian rutin yang sudah tersusun di dalam agenda gerakannya. Hal ini merupakan wujud dari motivasi terhadap para anggotanya agar tetap konsisten akan perjuangan gerakan dan juga pemahaman yang telah digariskan oleh pimpinan MTA. Karena itulah, pengikut MTA ini pun benar-benar militan untuk menjadi puritan. Mereka yang rajin mengikuti pengajian MTA biasanya berubah menjadi warga yang tidak mau mengadakan slametan, tidak mau menerima makanan slametan, kenduri, ritual dan sebagainya, tidak mau hadir di acara serupa bahkan tidak hadir dalam acara yasinan dan tablilan (Asroni, 2013: 216).

Dalam hal ini, MTA juga menekankan kepada para jamaahnya untuk senantiasa berpegang kepada Al-Qur'an dan hadis yang sahih, bukan tuntunan dari para guru, ustadz, atau kiai yang tidak menyebutkan dalil-dalil. Al-Qur'an dan sunah Rasulullah sebagai pedoman utama mesti paling diutamakan daripada hukum negara, 
terlebih hukum adat (Suryadilaga, 2015: 63). Bagi MTA, perkara yang tidak ada tuntunannya di dalam Al-Qur'an dan Hadis berarti adalah perbuatan bid'ah. MTA melihat bid'ah itu sesat dan tempatnya di neraka (Wawancara dengan Irw, 23 November 2017). Dari hal inilah kemudian, MTA berupaya terus mengingatkan para warganya untuk tetap istiqamah menjalankan praktik beragama yang murni dan tidak terpengaruh pada praktik beragama yang mencampurkan antara tradisi lokal dengan ajaran agama Islam.

Secara garis besar, berikut ini adalah bagan yang menggambarkan gerakan sosial MTA.

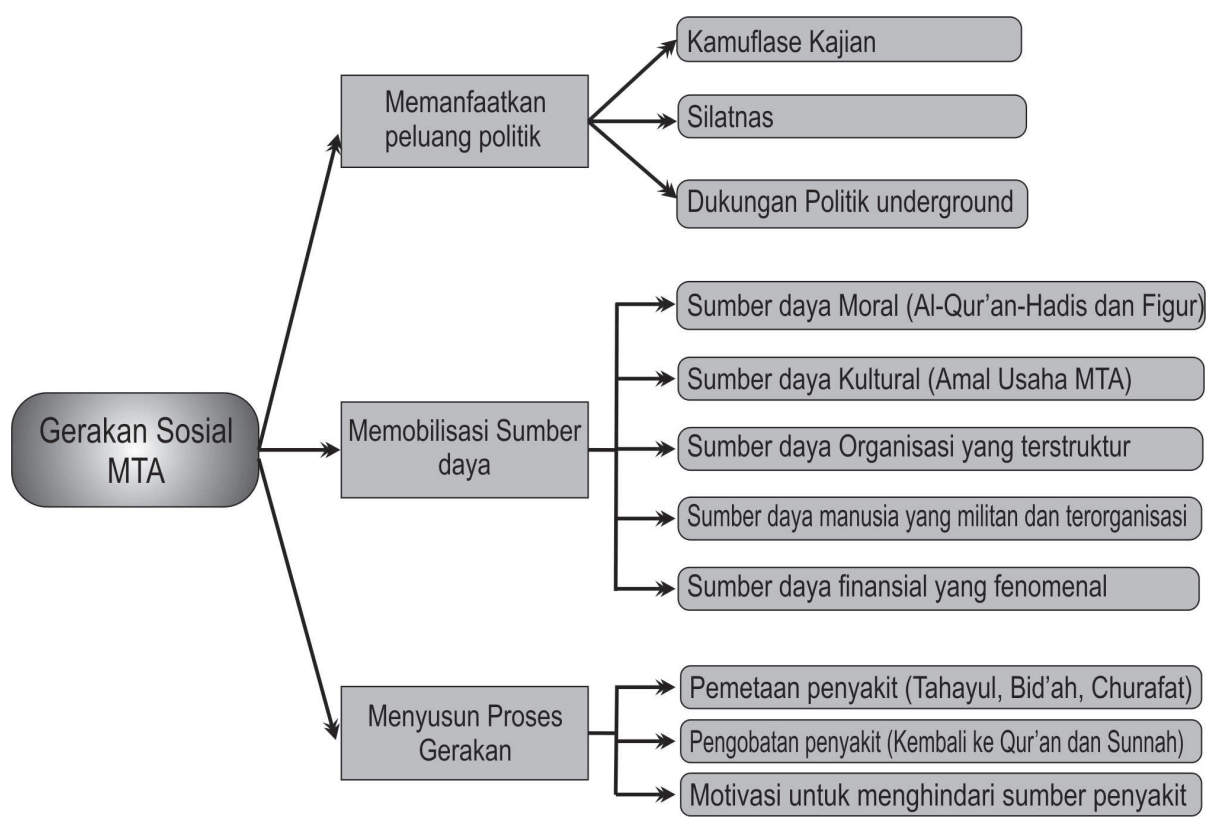

Itulah bentuk gerakan sosial yang dilakukan MTA dalam mengevolusi praktik keberagamaan yang menyimpang dalam pandangan MTA. Hal ini tentu saja kemudian memunculkan pro dan kontra yang tajam di tengah masyarakat yang majemuk dengan berbagai keragaman ekspresi keberagamaannya di Nusantara. Apalagi jika bersinggungan dengan kelompok Islam tradisionalis, seperti kalangan NU dan kelompok Islam abangan, sehingga tidak jarang terjadi konflik di antara kedua faksi yang berseberangan ini. 


\section{Kesimpulan}

Dari penjelasan di atas, dapat dipahami bahwa gerakan puritanis MTA merupakan sebuah yayasan yang bergerak laksana sebuah organisasi sosial yang dengan berbagai organ yang dimilikinya bergerak secara sistematis, terstruktur, dan tanpa kompromis dalam berdakwah. Karena sifatnya yang seperti itulah, MTA dapat dianalisis dengan menggunakan teori gerakan sosial. Hal itu dapat dilihat dari tiga aspek, yaitu: memanfaatkan peluang politik, memobilisasi sumber daya (moral, struktural, sosial-organisasional, SDM dan finansial), dan menyusun proses gerakan (framing process). Namun, dengan sifat dan gerakannya itu pulalah konflik terjadi dengan kalangan yang mereka serang, yaitu Islam tradisionalis dan Islam abangan.

\section{Daftar Pustaka}

Afida, Iklila Nur. 2015. Konflik Antara Majelis Tafsir Al-Qur'an (MTA) dan Nahdlatul Ulama (NU) dalam Praktek Keagamaan di Kabupaten Bantul, Skripsi, Jurusan Siyasah, Fakultas Syariah dan Hukum, UIN Sunan Kalijaga Yogyakarta, tidak dipublikasikan.

Alfandi, M. 2013. Prasangka: Potensi Pemicu Konflik Internal Umat Islam, Jurnal Walisongo, Volume 21, Nomor 1.

Ariyanto, Nur. 2010. Strategi Dakwah Majlis Tafsir Al-Qur'an (MTA) Melalui Radio MTA 107,9 FM Surakarta." Skripsi. Semarang: IAIN Walisongo, tidak dipublikasikan.

Asif, Muhammad. 2015. Sejarah Tafsir MTA (Majlis Tafsir Al-Qur'an)", Al-Itqan, Volume 1, No. 1.

Buechler, Steven M.1995. New Social Movement Theories. Dalam The Sociological Quarterly, Vol. 36, No. 3.

Edward, Bob, dan John D. McCarthy. 2004. Resources and Social Movement Mobilization," dalam David S. Snow, dkk. (ed.), The Blackwell Companion to Social Movement, UK: Blackwell Publishing. 
Gellner, Ernest. 1981. Muslim Society, Cambridge: Cambridge University Press.

Hassan, Riaz. 2002. Faithlines: Muslim Conception of Islam and Society, Oxford: Oxford University Press.

Ikhwani, Hasan. 2017. MTA Tidak Menafsir Al-Qur'an”, Harian Jawa Pos Edisi 21 September.

Isnanto, Bayu Ardi, Hadiri Silatnas MTA, Jokowi Ingatkan Indonesia Bangsa yang Besar, https://news.detik.com/berita-jawatengah/d-3646607/hadiri-silatnas-mta-jokowi-ingatkanindonesia-bangsa-yang-besar, diakses pada 1 Desember 2017.

Jinan, Mutohharun. 2013. Penetrasi Islam Puritan di Pedesaan: Kajian tentang Pola Kepengikutan Warga Majelis Tafsir Al-Quran, dalam Jurnal Profetika: Jurnal Studi Islam, Vol. 14, No. 2.

Jinan, Muthohharun. 2011. Dinamika Gerakan Islam Puritan di Surakarta: Studi tentang Perluasan Garakan majelis Tafsir alQuran, Kumpulan Makalah The 11th Annual Conference on Islamic Studies, Bangka Belitung.

Khalim, Samidi. 2016. Fatwa-Fatwa Keagamaan Penyebab Konflik: Analisis Isi Brosur Ahad Pagi MTA Surakarta", dalam Jurnal Penelitian Keislaman, Vol. 12, Nomor 2.

Kurtz, Lester R. 1995. Gods in the Global Village: The World's Religions in Sociological Perspective,California: Pine Forge Press.

Laili, Nihlatul. 2016. Majlis Tafsir Al-Qur'an (MTA) vs Nahdlatul Ulama (NU): Konflik Sosial Keagamaan Masyarakat Islam Jawa Tengah Tahun 1990-2013. Tesis, Program Ilmu Sejarah Universitas Gadjah Mada Yogyakarta, tidak dipublikasikan.

Locher, David A. 2002. Collective Behaviour, Upper Saddle River, New Jersey: Prentice Hall.

Majlis Tafsir Al-Qur'an, Profil Sekilas, http://www.mta-online.com/ sekilas-profil, diakses pada 1 Desember 2017. 
Ma'rifah, Indriyani, dan Ahmad Asroni. 2013. "Berebut Ladang Dakwah pada Masyarakat Muslim Jawa: Studi Kasus terhadap Konflik Majelis Tafsir Al-Qur'an (MTA) dan Nahdlatul Ulama (NU) di Kabupaten Purworejo," Jurnal Dakwah, Vol. XIV, No. 2.

McAdam, Doug, John D. McCarthy, dan Mayer N. Zald, (edi.) 1996. Comparative Perspectives on Social Movements: Political Opportunities, Mobilizing Structures, and Cultural Framings, Cambridge: Cambridge University Press.

Möller, André. 2005. Islam and Traweh Prayers in Java: Unity, diversity, and Cultural Smoothness, Indonesia and the Malay World.

MTA Memiliki 430 Cabang SeIndonesia, dalam www.antaranews. com/berita/395755/mta-memiliki-430-cabang-se-indonesia.

Mu'allim, Amir. 2012. Ajaran-Ajaran Purifikasi Islam Menurut Majelis Tafsir Al-Qur'an (MTA) Berpotensi Menimbulkan Konflik," dalam Jurnal Harmoni: Jurnal Multikultural dan Multireligius, Volume 11, Nomor 3.

Muhsin, Ilyya. 2015. Ummah dan Dawlah dalam Pandangan Gerakan Islam Politik: Studi tentang Gerakan Tarbiyah dan Hizbut Tahrir di Kampus UNS Surakarta", Disertasi, Program Doktor Sosiologi Universitas Gadjah Mada Yogyakarta, tidak dipublikasikan.

Mustolehuddin. 2014. Pandangan Ideologis-Teologis Muhammadiyah dan Majlis Tafsir Al-Qur'an: Studi Gerakan Purifikasi Islam di Surakarta, Jurnal Analisa, Volume 21 Nomor 01.

Noer, Deliar.1996. Gerakan Modern Islam di Indonesia 1900-1942, Jakarta: LP3ES.

Pimpinan Pusat Muhammadiyah. 1991. Pedoman hidup Islam Warga Muhammadiyah, Yogyakarta: Suara Muhammadiyah.

Presiden SBY Resmikan Gedung MTA di Surakarta, https://mta.or.id/ presiden-sby-resmikan-gedung-mta-di-surakarta. diakses pada 2 Desember 2017. 
Ritzer, George, dan Douglas J. Goodman. 2009. Teori Sosiologi: Dari Teori Sosiologi Klasik sampai Perkembangan Mutakhir Teori Sosial Postmodern, Penerj. Nurhadi, Yogyakarta: Kreasi Wacana, Cet. 2.

Snow, David, and Robert D. Benford. "Ideology, Frame Resonance, and Participant Mobilization." In Bert Klandermans, Hanspeter Kriesi, and Sidney Tarrow, editors, International Social Movement Research, Volume 1, From Structure to Action: Comparing Social Movement Research Across Cultures, hal. 197-217.

Sukino, Ahmad. 2012. "MTA Datang Menebarkan Kasih Sayang dalam Kekeluargaan," dalam Ahmad Sukino, Kumpulan Khutbah 2, Surakarta: Yayasan Majlis Tafsir Al-Qur'an.

Sukino, Ahmad. 2008. Menggapai Kemuliaan Hidup (Tanya Jawab Ahad Pagi) Jilid I Surakarta: Penerbit MTA, cet. ke-1.

Sunarwoto. 2012. Model Tafsir Al-Qur'an MTA (Majelis Tafsir AlQur'an) di Antara Tafsir dan Ideologi, Jurnal Refleksi, Volume 13, Nomor 2, April.

Sunarwoto. 2012. Gerakan Religio-Kultural MTA: Dakwah, Mobilisasi, dan Tafsir Tanding," Jurnal Afkaruna, Vol. 8 No. 2.

Sunarwoto. 2011. Antara Tafsir dan Ideologi Telaah Awal atas Tafsir Al-Qur'an MTA (Majelis Tafsir AlQur'an)," Refleksi, Vol. XII, No. 2.

Suryadilaga. 2015. Muhammad Alfatih "Majlis Tafsir Al-Qur'an dan Keberagamaan di Indonesia: Studi tentang Peran dan Kedudukan Hadis Menurut MTA," Masyarakat Indonesia, Vol. 41 (1).

Tarrow, Sidney. 1998. Power in Movement: Social Movements and Contentious Politics, Cambridge: Cambridge University Press.

Tim Penyusun Puslitbang Kehidupan Keagamaan. 2009. Kompilasi Kebijakan dan Peraturan Perundang-undangan Kerukunan Umat Beragama. Jakarta: Depertemen Agama, Badan Litbang dan Diklat, Puslitbang Kehidupan dan Keagamaan. 
Wakil Rais Syuriah PWNU Muhammad Adnan, Kunjungi Gedung MTA Pusat Surakarta, https://mta.or.id/category/berita-mtamajlis-tafsir-al-quran/ diakses pada 6 Desember 2017.

Wawancara dengan Irw, mantan anggota MTA, 23 November 2017.

Wawancara dengan Prof. Yoyok Mukhiyat, Ketua Umum MTA Pusat, di UNS Surakarta, pada tanggal 21 September 2017.

Wawancara dengan Sri Sadono, anggota Dewan Guru MTA Pusat yang secara rutin mengisi pengajian di MTA perwakilan Salatiga, 22 Oktober 2017.

Wawancara dengan Tontowi, Ketua MTA perwakilan Salatiga, 22 Oktober 2017.

Wikipedia.org, diakses 29 Nopember 2017.

Wildan, Muhammad. 2009. Radical Islamism in Solo: A Quest of Muslims' Identity in a Town of Central Java Indonesia, PhD dissertation, Bangi, Malaysia: Institute of Islamic World and Civilization, Universiti Kebangsaan Malaysia.

Wildan, Muhammad.2008. Mapping Radical Islam in Solo: A Study of the Proliferation of Radical Islamism In Central Java, Indonesia, Al-Jâmi'ah, vol. 46, no 1.

Woodward, Mark R. 1996. Talking Across Paradigms: Indonesia, Islam, and Orientalism, In Mark R. Woodward (ed.), Toward a New Paradigm: Recent Developments in Indonesian Islamic Thought, Temple: Arizona State University.

Zuhri, Syaifudin. 2009. Gerakan Purifikasi di Jantung Peradaban Jawa: Studi tentang Majlis Tafsir Al-Qur'an (MTA), Agus Moh. Najib, dkk., Gerakan Wahabi di Indonesia. Yogyakarta: Bina Harfa. 